Милош М. Ковачевић

Филолошки факултет у Београду

Филолошко-уметнички факултет у Крагујевцу

Филозофски факултет на Палама https://doi.org/10.18485/ai_zsjoski.2018.1.1

821.163.41.08 Андрић И. 821.163.41.09 Андрић И.

\title{
АНДРИЋЕВИ СТАВОВИ О ЈЕЗИКУ И СТИЛУ
}

Нема ниједнога рада у којему је Иво Андрић у цјелини представио своје ставове о језику и стилу. У неколико радова, посебно оних о Вуку Караџићу, али и у радовима који нису директно посвећени питањима стила и језика Андрић је успутно износио своја запажања о стилу и језику.

У овоме раду представљени су темељни Андрићеви ставови о стилу и језику уопште, као и о језичко-стилским особинама српскога („нашега”) језика, и то у саодносу са стилом и језиком самога Андрићевог текста.

Кључне ријечи: Иво Андрић, Вук Караџић, књижевни језик, језик књижевности, једноставан стил.

„Грађанска култура, наша 'висока' грађанска култура, висока модернистичка књижевност" - ријечи су Д. Бошковића - „своју сублимацију је иконизовала у Андрићу”, прије свега у његовом стилу, који је „савршен, у лингвистичком смислу бољи од језичког стандарда, од правописа, неподношљив у сопственој правилности, без сувишних ефеката и претерано 'чист' ('класицистички', рекли би филозофи)" (Бошковић 2017:199). Једном ријечју, Андрићев језик и стил представљају врхунац српског књижевног језика и стила ${ }^{1}$. Зато је, с једне стране, чудно да Андрић ни у једном

1 Уп.: „Андрићев језик је ваљда најскладнији и најхармоничнији српски језик у нашем досадашњем прозном стварању, умет- 
свом тексту није представио властите ставове о језику и стилу. Или тачније речено, нема ниједнога Андрићевог текста за који бисмо могли рећи да има у стилско-језичком погледу карактер програмског. С друге пак стране, није нимало чудно да је своје стилско-језичке опсервације Андрић најчешће исказивао у текстовима о Вуку Караџићу. Није чудо ако се зна да линија развоја нормативнога стила српскога језика и иде од Вука као зачетника до Андрића као његовог највећег остварења, као његовог врхунца² (уп. Ковачевић 2014:100-118).

А на Вука као почетак српскога језика и стила - често је указивао и сам Андрић. Чак у седам текстова Андрић говори о Вуку, с тим да је у шест од тих седам текстова, већ у наслову истакнуто Вуково име: „О Вуку као писцу”, „Вук, реформатор”, „Вуков пример”, „Вук и иностранство”, „Оптимизам Вука Караџића” и „Три слике из живота Вука Караџића” (Андрић 1981: 76-128). Седми Андрићев текст у коме он Вука има за „главног јунака”, иако његово име не истиче у наслову - носи за нашу анализу симптоматичан наслов „Нешто о стилу и језику” (Андрић 1981a:33-49). Осим тих седам текстова за анализу Андрићевих погледа на језик и стил врло битни су и текстови „Белешке за писца” и „Белешке о речима” (Андрић 1981a:50-65), као и поједине језичке „опсервације” у књизи Знакови поред nута (Андрић 2005). Управо ти текстови, придружимо

нички оплемењена сублимација његове интонације, која нас заноси још и данас у њеном изворно чистом и непрерађеном виду код Вука и Даничића, а која је - једном узлазном линијом од Вука и Даничића до Андрића - доспела код овог последњег до сложене уметничке оркестрације, која бруји и одзвања у нама додирујући и најтање струне нашег емоционално-мисаоног бића" (Живковић 1962:99).

2 Не треба заборавити да је Вука Андрић сматрао једним од главних својих језичких узора: „Ја сам језик учио код Вука, Његоша и из народних песама. Све пријатеље можете изгубити, али Вука и Његоша никако!” (Јандрић 1977: 149). 
ли им још само имагинарни „Разговор с Гојом” (Андрић 1981a: 9-28), представљају једини извор за тумачење не само Андрићевих ставова о Вуковом стилу и језику него и његових погледа на стил и језик уопште.

Па почнимо са Андрићевим односом према Вуку и Вуков(ск)ом српском језику. Вукову борбу за српски језик Андрић пореди са српским устанцима против Турака, тј. са „српском револуцијом”. Јер, „као што се у његовој Србији народ дигао просто 'да бије Турке', да би освојио власт у рођеној земљи, тако је и он кренуо да разгони славеносербске писатеље и да прибави власт народном језику као једином могућем основу истинске и савремене нащионалне културе"з (Андрић 1987: 27). У тој својој борби, нагласиће Андрић, „као сваки реформатор, Вук је био и рушилац и градитељ, и више градитељ него рушилац, али је савременицима, нарочито у прво време, морала бити много више видљива рушилачка страна његовог потхвата" (Андрић 1987: 26). А томе су понајбољи доказ чињенице да је у вријеме реформе Вук прије свега у Србији „био 'сербског језика помрачитељ'. Неписмени али утицајни људи говорили су Вуку у лице да нико од Косова до тада није нанео толико штете и срамоте српском народу као он. И због скупљања српских песама са њим су, како он сам каже, спрдњу терали. Годинама је наилазио на отпоре и неразумевања" (Андрић 1981a: 44-45). Али, истиче Андрић, „благодарећи њему” и „његовим личним везама и напорима ... српске народне умотворине продрле [су] у друге словенске и несловенске народе и стекле велику и широку популарност", с тим да је није безначајна ни чињеница да се и „Гете интересовао за појединости наше народне поезије и називао наш језик значајним језиком ('eine bedeutende Sprache')" (Андрић 1987:35). Сам Вук је, ријечи су Андрићеве, „рано схватио

3 Истицање у цитату је накнадно, наше - МК. 
важност онога што се данас назива компромитованом речју - пропаганда, и то је схватио на један за тадашње прилике необично модеран и реалан начин” (Андрић 1987:34), а сам је „дефинисао свој начин рада рекавши да се он труди дастрани народи упознају српски народ 'с најбоље стране, колико је могуће не вријеђајући истине" (Андрић 1987: 36), тако да је, оцјена је Андрићева, „не давши се смести, он постигао да се знање о српском народу, његовом језику и животу проширило у Европи и да су највећи и најумнији људи стали да изучавају наш језик на основу тих народних песама које је он под тако тешким погодбама сакупио и свету објавио” (Андрић 1987: 37).

При крају текста „Оптимизам Вука Караџића”, Иво Андрић јасно и концизно исказује свој однос не само према Вуковом српском језику него и према српскоме језику у Вуковоме дјелу. Андрић ће, наиме, рећи да најљепши споменик који Вуку можемо подићи „то су љубав и интересовање које ћемо посветити језику. Јер језик је, то сви знамо, жива снага са којом је везана не само култура него и само постојање једног народа. А питање језика - то је очигледно, али то треба стално понављати - није само ствар људи од науке и пера, српских и хрватских лингвиста и књижевника. Сви смо ми, без разлике, позвани да будемо творци и чувари језика, и сви ми, свесно или несвесно, утичемо на његов развитак, усавршавајући га или кварећи. А наша дужност је да чувамо оно што је Вук називао 'чистота и сладост нашега језика'4. [...] И са нашим се језиком, на његовом данашњем степену развитка, дешава исто што и са свима језицима света; и у њему се врши сталан процес стварања и рас-

4 Чистота језика, то је заправо језичка правилност - то је употреба књижевнога као народнога језика кристализованог Вуковим критеријумом „опћене правилности”. „Сладост” је пак оно што Т. Маретић (1899:672-673) назива „љепотом стила”, а односи се прије свега на захтјев да „штогод пишеш, нека не буде несклапно”. 
тварања; он се мути и бистри, бистри и мути, троши се и крњи, али и расте обнављањем, богаћењем и превазилажењем сама себе. Томе природном току ствари не може нико крај сагледати. Али једно се, мислим, може већ сада казати. У том развитку, у юеговој основи, биће као и до сада, увек присутан стваралачки дух Вука Стефановића Караиића"5 (Андрић 1981: 121-122).

Андрић, међутим, наглашава да није довољно само копирати Вука, јер опонашање нужно доводи до кризе, а „наша криза” - вели Андрић - „састоји се у томе да на неки начин превазиђемо Вука оставши му верни [истицање - МК]. Наша криза у стилском погледу је у томе што је нама тај језик узак, што ми за нове појмове морамо тражити нове речи и нове стилске обрте, а да при том не изневеримо Вука, јер се са тог темеља, са те основе несумњиво силазити не сме, јер тамо даље настаје анархија и неред” (Андрић 1981а:35). На том путу који подразумијева и вјерност Вуку и юегово превазилажене, „наши писци” - према Андрићевом мишљењу - „треба не само да су мајстори израза, него и чувари језика" (Андрић 1986: 115). А „знање језика” и „мајсторство израза" у нераскидивој су, иманентној вези. Свако ко се у свом послу користи језиком, па био он књижевник или научник - језик мора познавати. Очигледан симптом непознавања и „запостављања” свога језика, по Андрићевом мишљењу, представља тако честа употреба страних ријечи. Андрић ће рећи да „у књижевности треба употребити страну реч само онда кад се без ње не може, а то би требало да бива ретко” (Јандрић 1977:148), тако да не може да разумије „неке књижевне, ликовне и музичке критичаре; они као да за време писања држе пред собом речнике страних речи, као да им је и прва и последња намера: употребити што више страних израза! Ваљда

5 Истицање није Андрићево, него је накнадно, тј. наше - МК. 
мисле да ће тако испасти ученији; и често им то успева, јер у противном не би у толикој мери запостављали свој језик"; ту се посебно истичу књижевни критичари код којих се „разметање страним речима већ претвара у неукус”; али и телевизија, која се „још у колевци спајдашила са страним речима. Требаће доста времена и воље док се њени канали прочисте и од такве прљавштине” (Јандрић 1977: 149, 59, 83). За Андрића је непотребна употреба страних ријечи одраз некултуре једног народа, јер „по томе како се бори за чистоту свога језика може се мерити култура једног народа" (Јандрић 1977: 149).

Непознавање језика не огледа се само у употреби страних ријечи него и у непознавању као „површном познавању", за што Андрић наводи случај једног хрватског „археолога” с његовим трагичним непознавањем језика: „Непријатан (и помало тужан) пример” - вели Андрић „како наши људи мало и површно познају свој језик пружа чланак једног загребачког археолога, који сам читао ових дана. Чланак говори о гробовима из неолита који су откопани у Далмацији; у чланку се налази и овај став:

'Даље је значајно да мандибуле цијелих костура у блоковима 56, 64 и 72 нису имале доње зубе мудрости. Међутим, три остале мандибуле имају зубе мудрости.'

Тако тај човек преводи буквално и неспретно немачку реч Weisheitszahn или италијански dente del giudizio, док му на располагању стоји лепа наша реч умғак, за коју он, сиромах, као да није никад чуо" (Андрић 2005: 263).

За језик загребачког археолога Андрић ће рећи да је „непријатан пример”, али ће за језик Момчила Настасијевића рећи да је „трагичан случај”. Учествујући у расправи о Настасијевићевом књижевном умијећу (а заправо расправи о одбрани Настасијевићева језика), расправи коју је водио Станислав Винавер, Андрић ће рећи да је „питање језика најуспелије код онога писца код кога се као питање и не поставља. Код Настасијевића случај је 
трагичан [истицање - МК]. Опомиње на копање у тунелу и види се да нема друге стране, нема излаза" (Винавер 2012: 301).

Оваква оцјена Настасијевићева језика показује да Андрићу није био близак пут модерне лингвостилистике Бајијев(ск)ог типа, која је у први план стављала стилематичност језичких јединица као њихово структурно онеобичајено „ткање”, по чему се оне и разликују од уобичајених, општеупотребних јединица (о присуству тог стилистичког пута у српској књижевности в. исцрпно у Ковачевић 2012: 5-34; 2018: 1-21). Андрић није био за изразно онеобичајење, или друкчије речено Андрић није за употребу стилематичних језичких јединица, јер је, по његовом мишљењу, „,асно да хладно проучавање речника, све тражење, измишљање и комбиновање необичних речи и не воде ничему и да и највећа вештина у том послу не даје уметничко дело него, у најбољем случају, куриозан опит” (Андрић 1981a: 64). Зато и „изузетни ефекти, ако се сувише понављају, постају сметња; сва се пажња читаочева усредсреди на њих" (Андрић 2005: 324-325).

Андрићев пут је био пут стилогене надоградње народног и Вуков(ск)ог језика: да се познате и структурно ничим неонеобичајене јединице српскога језика (лексеме, синтагме, фраземе, реченице) доведу у друкчије комбинације, да им се прошири значење, да добију „нову улогу”, да својом познатошћу зазвуче непознато.

Андрић је у погледу карактеристика језика књижевности потпуно сагласан с погледима највећег српског лингвистичког ауторитета Александра Белића, који је Настасијевићеве језичке „иновације” прогласио „насиљем над језиком” (в. Ковачевић 2000). Стил се, по Белићу, може као „допуштен” једино остваривати у окриљу стандардног (књижевног) језика. Свако одступање од стандардног језика Белић сматра не само граматичком него и стилистичком погрешком. „Ја сам рекао” - вели 
Белић - „да и наш књижевни језик, као и сви други на свету, има своје законе и своја правила; али да језичка правилност негова нимало не смета слободноме стварану книжевника, исто онако као што тонови скала, који су за све музичаре исти, нису ни најмање спутавали генијалне полете великих музичких талената. Сваки ће добар писац, поштујући наш књижевни језик кроза се, дати му знаке свога стваралаштва, обогатити га у неком правцу. Он ће развијати његову унутрашњу и спољашњу лепоту, додајући му нове преливе у значењу и стварајући по готовим угледима - који су у њему самом као живи материјал и жива снага - нове речи за нове појмове. Њему није потребно да, тога ради, унакази, насилно поремети или повреди што у њему. Тако се ни у каквој уметности не постижу успеси од трајне вредности!" (Белић 1951:132). Белићев циљ је да покаже да „књижевници, који су ствараоци књижевнога језика, морају бити његови одлични познаваоци. Они су дужни да се брину и о лепоти и о чистоћи његовој; јер без лепоте језика нема ни лепоте књижевнога дела. Њихово право стварања нових особина књижевнога језика истиче из њихове дужности - одличнога познавања његова. [...] Сваки књижевник је и уметник. Он мора познавати добро књижевни језик који хоће да обогати и усаврши. Он не сме произвољно мешати све што год нађе, без разлога и без потребе” (Белић 1951:138). И Белић као најпозитивнији примјер доброга стила и језика истиче управо Андрића и његов језик и стил. Андрићев језик, ријечи су Белићеве, „потпуно је у границама књижевног 'канона'. Он не тражи ефеката каквим насиљем над правилношћу књижевног језика. Напротив, његов језик свуда одише њоме. Па ипак ни Андрићев стил ни његов језик нису укочени. Не види се чак да се ишло и најмање за тим да се правилност језика нарочито очува. Она је нешто што се подразумева" (Белић 1951:190). 
И сам Андрић је наглашавао да „ми морамо да смо на доброј нози са језиком којим пишемо, да смо у присном и сталном односу са њим, и то више и другачије него други људи. Са више напора и одговорности" (Андрић 1981a:64).

Много више но о језику, Андрић је, различитим поводима, говорио о стилу, увијек наглашавајући да је за постојање доброг стила нужан услов добро познавање језика, јер „тежња за савршенством изражајне форме за нас је служба садржини. А добро вршити ту службу, то јест јасно изразити своју мисао или своје осећање, ми можемо само онда ако смо савладали језик којим пишемо и стилски израз тога језика" (Андрић 1981a:42). И управо се онај Андрићев захтјев за превазилажење Вука, а да се притом Вук не изневјери - тиче прије свега стилске надоградње Вуковог језика. Андрић ће рећи да је „после Вукове победе настала криза”, „управо кризе раста, кризе развијања”, а та „криза у стилском погледу је у томе што је нама тај језик узак, што ми за нове појмове морамо тражити нове речи и нове стилске обрте, а да при том не изневеримо Вука" (Андрић 1981a:34-35). Та се криза, по Андрићу, препознаје прије свега у томе што „наш је језик добрим делом, као што неко рече, 'речник избледелих метафора' (Све на њему пева, Послови цветају, Кућа пева од чистоће и сл.). Наша књижевност као и наше новинарство патили су, нарочито после победе Вукове, од тог сликовитог говора који је стварно наслеђе Вуково, тј. резултат победе народног језика. После победе Вукове дошла је употреба па и злоупотреба народног израза, а он је редовито сликовит. (Не смије бити злоупотребе 'сликовитог говора', његове неукусне и декларативне употребе!)" (Андрић 1981а:39). Те „избледеле метафоре” заправо су језичке, устаљене, непоетске метафоре, метафоре као полисемије, неподводљиве под метафоре као стилске фигуре (уп. Ковачевић 2015:18). Однос између „избледеле метафоре” и „поетске метафоре” сугерише разлику коју су Пражани (Б. Хавра- 
нек прије свих) представили терминима аутоматизација и актуелизација. Аутоматизоване јединице су, како им и само име каже, устаљене, употријебљене готово по аутоматизму, док актуелизоване јединице подразумијевају дезаутоматизацију, јер актуелизацијом језички израз привлачи на себе пажњу и доживљава се као нешто необично, лишено аутоматизма. Носи више информација. Наиме, из теорије информација је познато да ће „количина информације бити већа уколико је предвидљивост неког елемента мања, а ако је предвидљивост потпуна, количина информације је равна нули" (Јовић 1985: 67-68). Из датог правила теорије информација јасно је да су све аутоматизоване јединице, а под њих потпадају и „избледеле метафоре” и сви општеупотребни „стални изрази” (нпр. стални епитети), информативно врло сиромашне, и као такве, будући лишене могућности преношења поетске информације „неподобне” за језик књижевности. И не само оне. Њима Андрић прикључује „инфлацију речи”, као „болест стила, где се изобиље претвара у сиромаштво, где гомилање речи личи на патогено множење ћелија код болести рака”. А „по закону инфлације”, - ријечи су Андрићеве - „што их више има, мање вреде и мање остављају утисак на читаоца. [...] То је нарочито случај са епитетима и атрибутима који се често претварају у злоупотребу придева" (Андрић 1981а:38). Преведено на закон теорије информације, то значи да је и код конструкције с „инфлацијом речи” количина информација равна нули. Маниристички употријебљене аутоматизоване, поетски неинформативне јединице, показатељ су неинвентивности, или досадности језика и стила некога писца. А „бојазан да се не буде досадан знак је правог, доброг и савесног писца” (Андрић 1986:115). „Тежња доброг писца” - вели Андрић - „треба да буде убедљив стил, а најубедљивији је једноставан стил. А Крилов је говорио: треба писати тако 
да речима буде тесно, а мислима пространо. Ту мисао он је одмах објаснио додавши: да реченицу треба глачати док не престане да буде досадна” (Андрић 1981a: 39).

Кондензовање, „глачање”, „збијање” реченице, по Андрићевом мишљењу, основни је поступак на путу ка добром стилу, с тим да је циљ кондензовања да се са што мањим бројем језичких јединица постигне што већи комуникативни учинак, или на поетски језик преведено, што богатија поетска информација. Тако ће Андрић у „Белешкама за писца” као савјет писцима написати: „Савијте сваку реченицу по десет пута преко колена, станите на сваку реч целом тежином, испитајте њену 'носивост, јер од тих кртих речи и слабих реченица треба да буде саграђен мост који ће непогрешно и неприметно пренети читаоца преко понора бесмисла и несвести у земљу живота и стварности, коју сте ви за њега и све људе успели да прикажете” (Андрић 1981: 60).

Можда је још сликовитије то „глачање реченице”, збијање у њу што више читаоцу видљивих смислова, Андрић исказао ријечима што их је у имагинарном разговору приписао сликару Гоји, о начину његовог сликања. „Мени је увек” - проговара Андрић Гојом - „малко сумњиво кад чујем где се говори: има хиљаду начина како се може сликати. Откуд хиљаду? [...] за мене има само један начин сликања. То је начин моје покојне тетке Анунцијате из Фуенте де Тодоса. Као дете гледао сам како та моја тетка учи своју кћер, мало старију од мене, да тка. Мала је седела за вратилом а тетка поред ње. Чунак је летео и вратило лупало, али је гласније од све лупе викала моја тетка при свакој нити и сваком ударцу.

- Збијај, збијај то боље! Што га жалиш? Збијај то јаче!

Мала се повијала под тим речима и ударала свом снагом, али тетки није ткање никад доста често ни збијено. По цео дан седи над девојчицом, и у њен бели раздељак у црној коси виче оштро: 
- Збијај! Гушће! Не ткаш сито!

Целог живота ја сам сликао под девизом те припросте и оштре жене” (Андрић 1981a: 21-22).

Па шта је, дакле, за Андрића добар стил, и шта су нужни услови доброга стила?

Питајући се „стил, шта је то?”, Андрић ће рећи: „Вештина заодети своју мисао, на најбољи и најубедљивији начин саопштити је другима? Кад добро размислим, чини ми се да би могао бити и много више од тога. Понекад ми се чини да је стил, то јест сам звук речи, реченица и склоп целине, уједно и главна проба истине коју та реченица носи” (Андрић 2005:323). „Кад неко увиди или осети једну чињеницу као истиниту и стварну, кад јој по свом унутарњем осећању нађе облик који њу најтачније приказује и објашњава другима, и кад то на најједноставнији могући начин каже или напише - то је стил којим се тај човек служи и којим је та одређена стварност најбоље казана" (Андрић 2005:324).

Добрим стилом не може се, по Андрићевом мишљењу, сматрати, без обзира на степен „глачања” и „збијања” реченице, „стил који је сврха сам себи”. Наиме, „то глачање мора да има своју меру и не треба да буде претерано, манијачко, само себи сврха" (Андрић 1981: 42-43). Друкчије речено, треба „не бити сувише ревностан ни доследан у том раду на стилу, јер треба знати да, невиђена и скривена, увек вреба на нас велика опасност да наш стил постане сврха сам себи, а затим да га наша самодопадност и наше самозадовољство упрегну у службу својих тиранских ћуди и прохтева. А то, то је већ болест, болест и крај уметности и уметничког стварања, и то болест коју приметимо тек кад је узела сувише маха." (Андрић 2005: 324).

Уз то не може бити доброга стила који не подразумијева усаглашеност теме и „начина причања”. Језички „искричав”, маркиран, али с темом несагласан стил, јесте 
стил без умјетничког ефекта, чест код „младог писца”: „Његов стил је сав од акробатија и ватромета. Тешкоће и опасности код оваквих даровитих и разиграних стилиста крију се у томе што је њима лако са успехом извести и најсмелији салто-мортале, а тешко или немогуће уздржати се и - не изводити га кад није време и где му није место” (Андрић 2005: 298).

Доброга стила, темељно је стилско Андрићево начело, нема без хармоније израза и садржаја. „Нема стила без садржине. Не постоји и не може постојати оно о чему се некад говорило, чак и у уџбеницима писало, такозвани добар стилист који сем стила нема ништа друго, добар стил са ниским или никаквим садржајем. Стил је само видљив или, ако хоћете, чујан део наше мисли или нашег осећања. Без мисли и осећања, нема стила, јер се гомила речи која личи на ниску празних прапораца не може ни звати стил. [...] Тежња за савршенством изражајне форме за нас је служба садржини. А добро вршити ту службу, то јест јасно изразити своју мисао или своје осећање, ми можемо само онда ако смо савладали језик којим пишемо и стилски израз тога језика" (Андрић 1981: 40, 42). И највећи стилисти српскога језика, попут нпр. Станислава Винавера, Андрићу су признавали „стилску уникатност”: „Ако је ико могао да говори о подударању израза и теме, онда је то Андрић. Али је он баш зато у нашој литератури једини, он је чудо. Признајемо му то. Другог таквог у нашој литератури нема. Код њега је потпуна хармонија између онога што је хтео, видео и рекао и чак оно што поједине личности кажу, или не кажу, у складу је са доживљеним током његове приповетке." (Винавер 2012: 308).

На питања „где да се учимо добром стилу? Како да радимо на њему?” Андрић одговара да се „учити треба, то је јасно, у народној књижевности, у старих писаца [никад не заборављајући Вука - МК]. Укратко: књиге су потребне, живот је неопходан. Једно не треба одвајати од 
другог” (Андрић 1981: 43-44). Због тога „стил треба да је нов, наш, израз нашег времена и његових тежњи, али он је у исто време заснован на тековинама свих пређашњих нараштаја, на културном наслеђу свих векова, исто као и на животу и говору живог народа"' (Андрић 1981a: 42).

А основ доброме стилу треба прије свега да буде народни језик, јер „народни језик, стихијски снажан а осетљив и прецизан као најфинији апарат, ради непрестано, решета, меље, мрви, одбацује оно што није за њега, а меси, глача и дотерује оно што задржи. Законе тога рада тешко је пратити. Ти закони представљају врло сложену мрежу у којој играју улогу нагони, атавизми, симпатије, интереси, често и ћуди, дубоке и тешко прозирне психе народне. Тако настају нове речи, лепе и снажне или необичне и ружне, али потребне и логичне по невидљивој потреби и несхватљивој логици народног обележавања и 'иментовања' ствари, људи и појава" (Андрић 1986: 60).

Добра потврда наведеном мишљењу јесте Андрићево запажање како се ти „народни закони”, та „психа народна” очитују и у начину прихватања одређених страних ријечи, њиховог прилагођавања домаћим „потребама”, какав је случај са ријечима „за извесне радње и поступке са негативним и тешким значењем", гдје над домаћом ријечју као дисфемизмом предност у народном језику добија конкурентна страна ријеч, али као еуфемизам, укорјењујући се и стичући на тај начин „право грађанства” у нашем језику: „У нас је” - вели Андрић - „постојала реч крематоријум и пре него што је таква установа уведена и њена зграда саграђена, и пре него је ико био спаљен, јер је давно већ прешла границу земље са штампом и науком. Не сећам

1 Овај Андрићев став потпуно је сагласан једном од темељних начела школе руских формалиста. Јер, „формалистичка истраживања открила су нам да је то истовремено очување традиције и прекид с њом оно што чини суштину сваког новог уметничког дела" (Јакобсон 1978:126). 
се да сам икад чуо глагол који означава акт спаљивања (cremare). Сада кад у Београду постоји крематоријум и почиње све више да се употребљава, чујете све чешће да је неко кремиран. Занимљиво је да нико не каже, ни у говору ни у штампи, спаљен.

Изгледа да за извесне радње и поступке са негативним и тешким значењем наши људи употребљавају пре стране речи него своје. (На пример: проституисати се, абортирати, ексцес, коитус и слично.)” (Андрић 2005: 326).

Зато је потребно добро познавати народни језик и његове „законе”, и тих се закона држати. У супротном долази се до кварења народног језика, какво Андрић уочава код значења ријечи „битисати”: „реч битисати не значи ово што јој данас приписују: егзистенцију, постојање, већ крај, смрт, завршетак. Код Шкаљића она значи: умријети, нестати. Настала је од турске речи битмек. Њена права употреба сачувана је у народу: 'И та миса битиса, оста Мате некрштен!' Политичари и филозофи искварили су ову реч давши јој значење које јој не пристаје” (Јандрић 1977: 137-138).

Иако би се по фреквенцији употребе у Андрићевим „стилским” написима могло закључити да је за њега ријеч упоришни језичко-стилски термин, ипак ријеч такав статус у Андрићевом виђењу стила нема - него тај статус од ријечи преузима реченица. Уосталом, то и сам Андрић наглашава: „За нас писце је” - вели Андрић - „пресуднија реченииа од речи” [истицање - МК]. „Не верујем да је богзна како препоручљиво хватати се по сву ноћ за главу и тражити ону такозвану 'јаку' реч која је кадра да понесе цео терет реченице. Не верујем да постоје такве речи. Боље је у том случају задовољити се неком другом речју, јер терет је на реченици, а не само на једној речи. То је отприлике као у спорту: цео тим мора да игра, а не само појединац” (Јандрић 1977: 273). „Вештина је пишчева да употреби праву реч на правом месту, а то је у писању 
најмучније постићи” (Јандрић 1977: 150), јер „речи навиру као рој пчела, а ви морате бити стрпљиви и међу хиљадама тражити матицу - ону праву реч; кад сте њу пронашли - и остале ће заузети смеран лет и стремиће ка наумљеном циљу” (Јандрић 1977:26). Друкчије речено, „језик је као река: све притоке се сливају у једно корито. Зато сам противник формуле коју је наметнула књижевна критика: свој језик. У питању је начин употребе и размештаја речи, а то је нешто друго” (Јандрић 1977: 344).

То теоријско начело о стилској супремацији реченице над ријечју једна је од најдоминантнијих црта самог Андрићевог стила. Већ је уочено да у Андрићевим дјелима лексика и није толико „богата, али да то и није важно важније је како се ријечи употребљавају и употребом мијењају и богате значења. У томе и јесте Андрићева величина - дати ријечима истинито, у свакој, посебној, ситуацији, одређено, а тачно, значење, прави и јединствен смисао” (Калезић 1985: 216). А да би то постигао, „Андрић је на изразу радио дуго и предано да би га учинио природним. Зато је био против 'кићења' и патетике јер таква врста израза није - истинита" (Калезић 1985:215).

Тај Андрићев рад на стилу при читању Андрићевих дјела остаје готово непримјетан, јер се Андрићев језик и стил доимају врло обичним и једноставним. Међутим, више је него јасно да иако „пише како дише човек, како му куца срце и струји крвоток: спонтано, конкретно, непосредно, органски”, и Андрић „зна за 'трикове' и зна за јадац - без њих се не може ни код Толстоја и они су и потребни - али је таква врста инструментаријума у његовим операцијама и поступцима тако употребљена да се та 'умешност' никада не осећа. И та је умешност преобраћена у уметност" (Лазаревић 1962: 334).

А то потврђује и сам Андрић сљедећом мишљу, која без сумње изражава суштину „читаве Андрићеве поетике књижевног језика" (Шутић 2005:32), мишљу да 
„нема те речи која је без везе са животом, као што нема биљке без подлоге која је храни. Значи да треба бити близак људима и њиховом животу, слушати њихов говор, упијати га у себе, размишљати о њему, живети са њим као брат са братом. И тада ћемо моћи постићи оно што треба, тј. да људима ЊИХОВИМ и ПОЗНАТИМ језиком кажемо НАШУ и НОВУ уметничку истину”, с тим да морамо бити свјесни да „речима нема краја, као ни нашој страсној борби с речима и за реч, ни нашем доживотном тражењу плодне и стваралачке речи. А то је она која долазећи од живих људи и људских дела али и људских снова и жеља, и прошавши кроз призму уметничког духа, постаје (у срећном случају) уметничко дело" [курзивно истицање - МК] (Андрић 1981a: 64-65).

Сам Андрић је, као што се види, верзално истакао упоришне појмове свог исказа, који посматрани ван контекста имају готово антонимско значење: ЊИХОВ НАШ; ПОЗНАТ - НОВ. Иако дати као антоними, ти појмови у датоме контексту ближи су синонимном значењу. Они, међутим, нису ни антонимни ни синонимни, него блискозначни, са значајном семантичком диференцијацијом. Јер, „њихов и познати” језик као такав није употријебљен у „умјетничком дјелу”, него је прошао „кроз призму умјетничког духа”, која је својеврстан стилистички процес прерастања „људских дела” у „уметничко дело”. Тако, како би Андрић рекао у „срећном случају” тај процес за резултат има књижевноумјетничко дјело. Тим процесом заправо се народни („њихов и познати језик”) преводи у поетски језик („наш и нов”), или друкчије речено: тим процесом (проласком „кроз призму уметничког духа") комуникативна функција народног као књижевног језика преводи се у поетску функцију језика књижевности. То је тај пут који омогућава да истовремено превазиђемо Вука, и да му останемо вјерни. Андрић тако не сматра да се у књижевности употребљава 
„сирови” народни као књижевни језик - него искључиво језик који је добијен процесом „проласка кроз призму уметничког духа", а то је поетски језик као језик књижевности, чија је тек подлога народни као књижевни или стандардни језик. (О односу књижевног језика и језика књижевности в. опширно у Ковачевић 2017: 45-67).

Суштину своје „поетике књижевног језика” као „језика књижевности" најбоље је изразио сам Андрић сљедећом максимом, у којој ријеч поезија треба читати у значењу ријечи књижевност, а ријеч пјесник у значењу ријечи књижевник: „Највећи ефекат” - вели Андрић - „постизава се у поезији кад песнику пође за руком да читаоца изненади нечим познатим" (Андрић 2005: 322). Дата је мисао заиста најсуштаственија дефиниција Андрићевог виђења суштине књижевног стила, али и језика књижевности уопште.

\section{Литература}

Андрић 1981: Ivo Andrić, Umetnik i njegovo delo, Sabrana djela Ive Andrića, Knjiga trinaesta, Sarajevo: Udruženi izdavači (Svjetlost Sarajevo, Prosveta Beograd, Mladost Zagreb, Državna založba Slovenije Ljubljana, Misla Skopje, Pobjeda Titograd), 1981. Андрић 1981a: Ivo Andrić, Istorija i legenda, Sabrana djela Ive Andrića,

Knjiga dvanaesta, Sarajevo: Udruženi izdavači (Svjetlost Sarajevo, Prosveta Beograd, Mladost Zagreb, Državna založba Slovenije Ljubljana, Misla Skopje, Pobjeda Titograd), 1981.

Андрић 1986: Андрићев азбучник: искуства, запажања и мисли, изабрао и саставио Слободан Глумац, Нови Сад: Матица српска, 1986.

Андрић 1987: Вуку Андрић, приредио Милан Ђоковић, Београд: Задужбина Иве Андрића, 1987.

Андрић 2005: Иво Андрић, Знакови поред пута, тематизовао Радоман Рацо Станишић, Подгорица: Фондација „Радоман Рацо Станишић”, 2005. 
Белић 1951: Александар Белић, Око нашег книжевног језика, Београд: СКЗ, 1951.

Бошковић 2017: Драган Бошковић, Грађанска култура, нарација, филм, модернизам, жеља: Андрић и Мир Јам, Кюижевна историја, XLIX/162, Београд, 2017, 197-209.

Винавер 2012: Станислав Винавер, Одбрана песништва: Есеји и критике о српској книжевности 2, приредио Гојко Тешић, Београд: Службени гласник, Завод за уџбенике, 2012.

Живковић 1962: Драгиша Живковић, Епски и лирски стил Ива Андрића, у: Иво Андрић, уредник Војислав Ђурић, Београд: Институт за теорију књижевности и уметности, 1962, 81-103.

Јакобсон 1978: Roman Jakobson, Ogledi iz poetike, Beograd: Prosveta, 1978.

Јандрић 1977: Љубо Јандрић, Са Ивом Андрићем 1968-1975, Београд: СКЗ, 1977.

Јовић 1985: Dušan Jović, Jezički sistem i poetska gramatika, Beograd: BIGZ, Priština: Jedinstvo, 1985.

Калезић 1985: Vasilije Kalezić, Ivo Andrić u našim sporovima, Ljubljana - Beograd: Partizanska knjiga, 1985.

Ковачевић 2000: Милош Ковачевић, Белићеви погледи на стилистику, Српски језик, V/1-2, Београд, 2000, 127-143. (прештампано у: Граматичке и стилистичке теме, Бања Лука: Књижевна задруга, 2003, 197-219.)

Ковачевић 2012: Милош Ковачевић, Лингвостилистика кюижевног текста, Београд: СКЗ, 2012.

Ковачевић 2014: Милош Ковачевић, Андрићев језик и стил врхунац Вуковог стила и језика, Вук Стефановић Карачић и Иво Андрић или Иво Андрић на Вуковом путу, уредник Станислава Андрић, Херцег Нови: СКПД Просвјета, 2014, $100-118$.

Ковачевић 2015: Милош Ковачевић, Стилистика и граматика стилских фигура, IV битно допуњено издање, Београд: Јасен, 2015.

Ковачевић 2017: Милош Ковачевић, Српски књижевни језик и језик књижевности, Српски језик под лупом науке, Београд: Завод за уџбенике, 2017, 45-67. 
Ковачевић 2018: Стилистика у настави српскога језика, Кюижевност и језик, LXV/1-2, Београд, 2018, 1-21.

Лазаревић 1962: Бранко Лазаревић, Андрићев комплекс, у: Иво Андрић, уредник Војислав Ђурић, Београд: Институт за теорију књижевности и уметности, 1962, 331-334.

Маретић 1899: Томо Маретић, Граматика и стилистика хрватскога или српскога књижевног језика, Загреб, 1899.

Шутић 2004: Милослав Шутић, Андрићеве рефлексије о уметничком стварању, у: Андрић у систему уметности, зборник радова, уредник Милослав Шутић, Београд: Институт за књижевност и уметност; Бања Лука: Књижевна задруга, 2004, 11-34.

Miloš Kovačević

\section{ANDRIĆ'S VIEWS ON LANGUAGE AND STYLE}

There is no study that presents Ivo Andrićs complete views on language and style. In several papers, especially those on Vuk Karadžić, and also in certain not directly concerned with matters of style and language, Andrić inadvertently expressed his notions of style and language.

This paper presents Andrićs fundamental views both on style and language in general and linguo-stylistic features of Serbian ("our") language in correlation to the style and language of Andrićs own texts.

Andrić assumed that a writer's objective was to surpass Vuk (Karadžić) and at the same time stay true to him. On that path writers must be masters of expression as well as the guards of a language. In terms of style, it has to be convincing and the most convincing one is the plain one. In Andrićs opinion, that is why sentence condensing, "polishing" and "compressing" is a basic method on the road to a good style. The goal of this condensing is to achieve a greater communicative effect using smaller number of 
linguistic units, or in poetic language terms - achieving the richer poetic information.

The whole Andrićs poetics of literary language is contained within his maxim "people should be told in THEIR and FAMILIAR language OUR and NEW artistic truth". However, that is always accomplished in the cases when a writer "manages to surprise readers by something familiar".

Key words: Ivo Andrić, Vuk Karadžić, poetic language, literary language, plain style. 